\title{
Гігієнічна діагностика хронотипів та хронотипологічних особливостей організму спортсменок
}

\author{
УДК 613.07:796 \\ О. І. Циганенко, Л. М. Путро, Н. А. Склярова,
Л. Ф. Оксамитна
}

\begin{abstract}
Національний університет фізичного виховання і спорту України, Київ, Україна
\end{abstract}
Резюме. Встановлено, що біоритмологічні чинники організму людини становлять наукову проблему, оскільки можуть суттєво впливати на функціональний стан і спортивні результати спортсменів. Мета. Розробити методологічні підходи до проведення гігієнічної діагностики хронотипів та хронотипологічних особливостей у спортсменок. Методи. Теоретичний аналіз наукової літератури: узагальнення, синтез, формалізація, абстрагування. Результати. Розроблено методологічні підходи до проведення гігієнічної діагностики хронотипів у спортсменок (ранковий, денний, вечірній) та їх хронотипологічних особливостей (ступінь прояву), визначення стану біоритмологічної адаптації до циркадних біоритмів (високий, середній та недостатній), в тому числі і за умов високих фізичних навантажень. Вони включають визначення хронотипів та їх хронотипологічних особливостей у спортсменок з використанням спеціальної анкети, яка враховує особливості спортивної діяльності, та анкети для визначення ступеня напруженості механізмів процесу біоритмологічної адаптації, в тому числі за умов високих фізичних навантажень із застосуванням анкетно-опитувального методу, проведення аналізу фазової архітектоніки та синхронності циркадних біоритмів серцевих скорочень та температури тіла для визначення стану біоритмологічної адаптації. Результати свідчать, що розроблені підходи можуть бути апробовані в дослідженнях.

Ключові слова: спортсменки, гігієнічна діагностика, хронотип, хронотипологічні особливості, біоритми, біоритмологічна адаптація.

\section{Hygienic diagnosis of chronotypes and chronotypological features of female athletes}

\section{O. I. Tsyhanenko, L. M. Putro, N. A. Skliarova, L. F. Oksamytna}

National University of Physical Education and Sport of Ukraine, Kyiv, Ukraine

\begin{abstract}
It is established that biorhythmological factors of the human body represent a scientific problem, as they can significantly affect the functional state and sports results of athletes. Objective. Develop methodological approaches to the hygienic diagnosis of chronotypes and chronotypological features in female athletes. Methods. Theoretical analysis of scientific literature: generalization, synthesis, formalization, abstraction. Results. Methodological approaches to hygienic diagnostics of chronotypes in female athletes (morning, day, evening) and their chronotypological features (degree of manifestation), determination of biorhythmological adaptation to circadian biorhythms (high, medium and insufficient), including under conditions of high physical loads have been developed. They include determination of chronotypes and their chronotypological features in female athletes using a special questionnaire that takes into account the peculiarities of sports activity and that to determine the degree of intensity of the mechanisms of biorhythmological adaptation, including in conditions of high physical loads using questionnaires, analysis of phase architectonics and synchrony of circadian biorhythms of heart contractions and body temperature to determine the state of biorhythmological adaptation. The results indicate that the developed approaches can be tested in research.
\end{abstract}

Keywords: female athletes, hygienic diagnosis, chronotype, chronotypological features, biorhythms, biorhythmological adaptation. 
Постановка проблеми. Аналіз наукової, науково-методичної літератури та інших джерел інфоормації показав, що біоритмологічні чинники організму людини становлять наукову проблему, оскільки можуть суттєво впливати на адаптацію, в тому числі і до високих фрізичних навантажень, на функціональний та психічний стан і спортивні результати спортсменів $[7,9,10,13]$.

Усе сказане потребує спеціального методологічного забезпечення для подальшого наукового вивчення та розробки цієї проблеми. За методологічними аспектами це стосується таких питань сучасної хроногігієни стосовно спорту, як гігієнічна діагностика хронотипів (ранковий, денний, вечірній) та хронотипологічних особливостей (ступінь прояву), стану та напруженості механізмів біоритмологічної адаптації (хроноадаптації) [2, 4, 10].

Щодо термінології, то гігієнічну діагностику визначають як профілактичну за спрямуванням діагностику, суть якої полягає в дослідженні чинників довкілля та їх впливу на фізичний стан і здоров'я людини, іï працездатність. Ії̈ розглядають як ключовий елемент у системі сучасних медико-профрілактичних технологій [8]. Відповідно гігієнічну хронодіагностику (як один 3 напрямів гігієнічної діагностики та хроногігієни взагалі) визначають як гігієнічну діагностику у часі і викладають у медичних закладах вищої освіти (3ВО) у курсі дисципліни «Гігієна та основи екології» як складову хроногігієни $[2,4,8,9]$. При цьому необхідно відмітити, що одним з основних об'єктів та предметів досліджень у хроногігієні $\epsilon$ хронотип та його особливості $[2,4,8,9]$.

Термін «хронотип» (англ. chronotype) стосовно людини визначать як трудову діяльність, у тому числі і спортивну, в оптимальний для організму людини час доби (ранок, день, вечір) [2, 12].

Хронотипи людини генетично обумовлені і мають хронотипологічні особливості, такі як ступінь прояву та пристосування (адаптації) до різних часових режимів та їх змін (різна подовженість світлового дня, в тому числі полярного дня та полярної ночі тощо), різну поширеність серед груп та популяцій людини, враховуючи i спортсменів, у тому числі і за статевим аспектом (жіноча-чоловіча стать). Їх визначення базується на оцінці циркадних (добових) біологічних ритмів організму людини, їх стану $[1,2,7,11,12]$.

Достатній ступінь адаптації біологічних циркадних ритмів людини визначають як стан, коли фазова архітектоніка циркадної (добової) системи та синхронність її ритмів у більшості ланцюгів (добова динаміка частоти серцевих скорочень, температури тіла тощо) чітко проявляються. Адаптацію (хроноадаптацію) біологічних циркадних (добових) ритмів можна певною мірою віднести до функціональної адаптації [10].

Проте при цьому в методологічному плані необхідно відмітити, що ще не розроблені методологічні підходи (шляхи) до проведення гігієнічної діагностики хронотипів та їх хронотипологічних особливостей, визначення ступеня напруженості механізмів біоритмологічної адаптації та її стану відносно циркадних (добових) біоритмів у спортсменок, у тому числі і за умов високих фрізичних навантажень. Тому розробка цих положень $\epsilon$ своєчасною і актуальною.

Роботу виконано згідно з планом НДР «Функціональна і психологічна адаптація організму спортсменок до великих фрізичних навантажень».

Мета дослідження - розробити методологічні підходи до гігієнічної діагностики хронотипів та їх хронотипологічних особливостей у спортсменок.

Методи дослідження: аналіз наукової, науково-методичної літератури та інших джерел інфрормації; узагальнення, синтез, формалізація, абстрагування [5].

Результати дослідження та їх обговорення. Проведений аналіз наукової, науково-методичної літератури та інших джерел інформації показав, що проблемі хронотипів та їх визначення у спортсменів приділяється значна увага не тільки в Україні, а й за кордоном [4, 12-16]. Мають місце певні методологічні розробки визначення хронотипів, а також хронотипологічних особливостей у спортсменів, у тому числі і спортсменок за напрямом біоритмологічна адаптація $[6,7,10]$.

Існують методологічні підходи, де хронотипологічні особливості спортсменок (наприклад, спринтери та стаєри) оцінювали за показниками, які характеризують не безпосередню адаптацію біоритмів (біоритмологічну адаптацію), а взагалі функціональну адаптацію організму [6]. Проте такого роду дослідження не спрямовані на адаптацію біоритмів (біоритмологічну адаптацію) і потребують багато часу та значного інструментального і кадрового забезпечення для проведення оцінювання функціональної адаптації.

У цьому плані необхідно відмітити, що взагалі для визначення та оцінювання хронотипів людини використовують тести - методики опитування із застосуванням спеціально розроблених для цього анкет загального спрямування, однак без урахування специфріки діяльності (трудової, спортивної тощо) осіб, які беруть участь в опитуванні $[1,2]$. 
До цієї категорії можна віднести методику тест-опитування шведського вченого О. Остберга (містить 23 пункти запитань), тест-опитувальник Г. Ламперта (вісім пунктів запитань), тестметодику Г. Хільденбранта та багато інших [1, 2, $4,7]$. Але вони не дають можливості визначати хронотип та його хронотипологічні особливості у спортсменок з урахування їхньої спортивної діяльності.

3 огляду на сказане, для гігієнічної діагностики хронотипу (ранковий, денний, вечірній) та його хронотипологічних особливостей (ступінь прояву) у спортсменок з урахуванням їхньої спортивної діяльності пропонується використовувати спеціальну анкетно-опитувальну методику гігієнічної діагностики, яка враховує вказані особливості за бальною оцінкою отриманих результатів [12]. Анкета містить шість пунктів запитань і дає можливість визначати не тільки основні достатньо виражені хронотипи, а і їх хронотипологічні особливості, а саме ступінь прояву хронотипу (слабко виражений, сильно виражений) [13]. Додатково під час гігієнічної діагностики хронотипів та їх хронотипологічних особливостей (з урахуванням прояву хронотипу) проводиться визначення ступеня напруженості процесів біоритмологічної адаптації стосовно циркадних біоритмів.

У методичному аспекті це виконується обов'язково тільки після визначення хронотипу та його хронотипологічних особливостей у спортсменок 3 наступним повідомленням їм результатів визначення. Для цього пропонуємо розроблений нами анкетно-опитувальний метод гігієнічної діагностики ступеня напруженості механізмів біоритмологічної адаптації (хроноадаптації) організму спортсменок відносно циркадних (добових) біоритмів з бальною оцінкою отриманих даних з використанням для цього спеціальної анкети.

Вона складається з таких запитань:

1. Як Ви адаптуєтеся до систематичної зміни добового часового режиму занять спортивною діяльністю: дуже добре - 1 бал; добре - 2 бали; індиферентно - 3 бали; погано - 4 бали, дуже погано - 5 балів.

2. Чи $є$ у Вас зниження фрізичної працездатності, коли режим занять спортивною діяльністю не відповідає Вашому хронотипу (ранковий, денний, вечірній): немає - 1 бал; дуже незначне 2 бали; значне - 3 бали; дуже значне - 4 бали; «катастроорічне» - 5 балів.

3. Чи є у Вас зниження психічної працездатності, коли режим занять спортивною діяльністю не відповідає Вашому хронотипу: немає - 1 бал; дуже незначне - 2 бали; значне - 3 бали; дуже значне - 4 бали; «катастрофрічне» - 5 балів.
4. Чи виникає у Вас швидкий прояв втоми при добовому режимі занять, який не відповідає Вашому хронотипу: немає - 1 бал; не дуже часто 2 бали; нечасто - 3 бали; часто - 4 бали; дуже часто - 5 балів.

Оцінювання проводять за такою схемою: загальна кількість - 20 балів; незначна напруженість механізмів біоритмологічної адаптації - від 16 до 20 балів; середня напруженість механізмів біоритмологічної адаптації - від 10 до 15 балів; значна напруженість механізмів біоритмологічної адаптації - від 9 і нижче балів.

Для гігієнічної діагностики хронотипів та їх хронотипологічних особливостей за умов впливу на організм різних чинників, у тому числі і високих фрізичних навантажень, рекомендується ще додатково провести дослідження 3 визначення фразової архітектоніки циркадних біоритмів та ступеня їх синхронізації, тобто визначення стану біоритмологічної адаптації (хроноадаптації).

У методологічному плані як критеріальні показники біоритмологічної адаптації організму, а саме оцінювання фразової архітектоніки та ступеню синхронізації циркадних біологічних ритмів, можуть насамперед використовуватися біоритмологічні характеристики циркадних ритмів серцевих скорочень та температури тіла [2, 10].

Для визначення характеру впливу різних чинників довкілля на біометричні особливості циркадних ритмів досліджується фрорма денного відрізку хронограми - кривої, і на основі отриманих даних здійснюється їх бальне оцінювання. При цьому найчастіше методологічно застосовується аналіз саме добового хвильового режиму біоритмів: вираховуються три основних параметри хвильової хронограми: мезор (середнє значення або рівень), амплітуда коливань та акрофраза (момент часу, коли коливання досягають свого максимуму) $[2,7]$.

У ході дослідження найвищу оцінку - 5 балів - отримують паралелоподібні криві з максимальною акрофазою о 12 або 16 годині; 4 бали - двовершинні; 3 бали - паралелоподібні криві 3 максимальною акрофразою о 20 годині; 2 бали - платоподібні криві; 1 бал - інвертовані криві [2].

За такого оцінювання можна зарахувати, що 5 балів буде відповідати високому стану біоритмологічної адаптації, 3-4 бали - середньому стану, 1-2 бали - недостатньому стану біоритмологічної адаптації (хроноадаптації) за умов дії різних чинників, у тому числі і високих фрізичних навантажень.

Під час проведення аналізу хвильових процесів (хронограм) можуть застосовуватися і спе- 
ціальні комп'ютерні програми аналізу біоритмів хвильових процесів [7].

Для більш детального та поглибленого за методологічним рівнем виконання такого роду досліджень уже почали застосовувати і спеціальні апаратно-програмні комплекси, такі як $\mathrm{AПK}$ «Baрикард». Методологічно та методично їх робота базується на інструментальних технологіях експресного аналізу біологічних ритмів організму людини, насамперед циркадних (добових) ритмів серцевих скорочень, які виділяють 3 електрокардіосигналів та обробляють 3 використанням спеціальної інформаційної комп'ютерної програми. Такі інструментальні медичні технології відносять до категорій інноваційних технологій медичної діагностики [3].

Зазначимо, що в методологічному аспекті 3 використанням медичних діагностичних технологій, які закладені в АПК «Варикард», та приладів подібного типу можна проводити діагностику функціонального стану організму під час професійного відбору, у тому числі і спортсменів: діагностику регуляції біоритму серцевих скорочень та стану адаптаційних реактивних систем при екстремальній дії на організм різних чинників, у тому числі і великих фрізичних навантажень; визначення ефрективності проведених профрілактично-лікувальних заходів тощо [3].

Таким чином, проведення гігієнічної діагностики у спортсменок хронотипів та їх хронотипологічних особливостей рекомендується здійснювати за двома етапами досліджень. Спочатку (перший етап) проводиться з використанням тестанкети опитування визначення хронотипів спортсменок 3 урахуванням їх хронотипологічних особливостей (слабкий, сильний прояв) [13]. На другому етапі проводиться визначення ступеня напруженості механізмів процесів біоритмологічної адаптації (хроноадаптації) із застосуванням запропонованої нами для цієї мети анкети опитування.

Додатково за умов дії на організм спортсменок різних чинників, у тому числі високих фрізич-

\section{Література}

1. Балбатун АO. Методы диагностики и значение хронотипов человека [Diagnostic methods and the role of human chronotypes]. Медицинские знания. 2011; 1: 24-26.

2. Бардов ВГ, Сергета IB. Загальна гігієна та екологія людини (Основи психогігієни та хроногігієни) [General hygiene and human ecology (Fundamentals of psychohygiene and chronohygiene)]: Навч. посібник для медичних 3ВО. Вінниця: Нова книга. 2002: 185-207.

3. Билявский ЮЮ, Сучкова ЖВ, Булатецкий СВ, Шустова СЛ. Сравнительный анализ программных комплексов для изучения вариабильности сердечного ритма [Comparative analysis of program systems for studying heart rate variability]. Режим доступа: http: cyberleninka ru., 2020. них навантажень, може проводитися визначення фразової хроноархітектоніки циркадних (добових) біологічних ритмів частоти серцевих скорочень та температури тіла для оцінювання стану біоритмологічної адаптації.

Методично гігієнічна діагностика фразової архітектоніки циркадних (добових) біологічних ритмів серцевих скорочень та температури тіла виконується шляхом дослідження денного відрізку хронограм, що включає врахування трьох основних параметрів: мезор, амплітуда коливань та акрофраза з наступною бальною оцінкою отриманих результатів $[1,2,7]$.

У разі необхідності для більш детального та поглибленого вивчення фразової архітектоніки циркадних (добових) біологічних ритмів спортсменок та їх синхронності можуть застосовуватися і спеціальні апаратно-програмні комплекси типу АПК «Варикард» з використанням спеціальних інформаційних комп'ютерних програм, таких як «Cosinor Ellipse 2006» тощо [3, 7].

\section{Висновки}

Розроблені методологічні підходи до проведення гігієнічної діагностики хронотипів та їх хронотипологічних особливостей у спортсменок, що включають гігієнічну діагностику визначення хронотипів у спортсменок та їх хронотипологічних особливостей (ступеня прояву), а також оцінювання ступеня напруженості механізмів біоритмологічної адаптації, в тому числі і за умов високих фрізичних навантажень.

Для оцінювання стану біоритмологічної адаптації за умов впливу на організм спортсменок різних чинників, у тому числі і високих фрізичних навантажень, діагностику доцільно проводити на основі аналізу фазової архітектоніки та синхронності хронограм циркадних (добових) біологічних ритмів серцевих скорочень та температури тіла.

Перспективи подальших досліджень передбачають проведення дослідження з гігієнічної діагностики хронотипів та їх хронотипологічних особливостей у спортсменок.

4. Бородин ЮИ, Труфакин ВА, Шурлыгина АВ, Склянова НА. Основы биоритмологии, хроногигиены и хронопрофилактики [Fundamentals of biorhythmology, chronohygiene and chronoprophylaxis]: Учебное пособие. Новосибирск: СО РАМН; 2011. 63 с.

5. Гуторов ОІ. Методологія та організація наукових досліджень [Methodology and organization of scientific studies]: Навч. посібник. Харків: XHAY; $2017.57 \mathrm{c}$.

6. Захарьева НН. Хронотипологические особенности спортсменок, занимающихся циклическими видами спорта [Chronotypological features of female athletes involved in cyclic sports events]. Теория и практика физической культуры; 2011. 1; 17-20. 
7. Корягина ЮВ. Хронобиологические основы спортивной деятельности [Chronobiological bases of sports activity]: монография. Омск: Изд-во СибГУФК; 2008. 227 с.

8. Кузьмин ЕА. Гигиеническая диагностика - ключевой элемент медико-профилактических технологий [Hygienic diagnostics - a key element of medical and preventive technologies]. Гигиена и санитария. 2015; 94(2): 99-104.

9. Лунева ОГ. Хронодиагностика доклинических нарушений здоровья спортсменов и патофизиологическое обоснование их хронокоррекции [Chronodiagnostics of preclinical health disorders in athletes and pathophysiological substantiation for their chronocorrection]. [Автореферат]. Владикавказ. 2010. 18 с.

10. Методические рекомендации по интерпретации влияния биоритмологических факторов на адаптацию, функциональное и психологическое состояние и спортивный результат московских спортсмеHOB [Methodical recommendations for the interpretation of the influence of biorhythmological factors on the adaptation, functional and psychological state and sports results of Moscow athletes]. Москва: Департамент спорта города Москвы; 2012. 40 c.

11. Хаснулин ВИ, Хаснулина ВП. Хронотип и устойчивость к психоэмоциональному стрессу в дискомфортных климатических условиях [Chronotype and resistance to psychoemotional stress in uncomfortable climatic conditions]. Фундаментальные исследования. 2012,12-1:154-160.

tsyhanenko.oleh@gmail.com

putro.liudmyla@gmail.com

sklayrova.natalia@gmail.com

oksamytna.liudmyla@gmail.com
12. Циганенко ОІ, Уряднікова IB, Склярова НА. Проблема гігієнічної діагностики хронотипів спортсменів та шляхи її вирішення. Збірник статей V Міжнародної науково-практичної інтернет-конференції «Актуальні проблеми медико-біологічного забезпечення фізичної культури, спорту та фізичної реабілітації» [The problem of hygienic diagnosis of chronotypes of athletes and ways to solve it. Collection of articles of the $\mathrm{V}$ International scientific-practical Internet conference «Actual problems of medical and biological support of physical culture, sports and physical rehabilitation»]. Xapків: ХДАФК. 2019. 51-58.

13. Циганенко ОІ, Першегуба ЯВ, Склярова НА, Оксамитна ЛФ. Проблема визначення біоритмології спортсменів [The problem of determining the biorhythmology of athletes]. Науковий часопис НПУ ім. М.П. Драгоманова. Серія 15. 2018; 18(98): 175-179.

14. Kunorozva Z. Chronotype and PERIOD3 varitable number tandem repeat polymorphism in individual sports athletes. Chronobiol Intarnational. 2012; 29(8): 1004-1010.

15. Laborde S. Chronotype sports particulation and positive personalitetrain-like individual differences. Chronobiol Intarnational; 2015; 32(7): 942-951.

16. Rossia A. The effect of chronotype on psychophysiological responses during aerobic self-passed exercises. Percept Mot Skills. 2015; 121(3): 840 850. 